\title{
Gender Difference in Leadership: An Empirical Study of Select Banks
}

\author{
Asima Mushtaq $^{1 *}$ and Nair UI Nisa ${ }^{2}$ \\ ${ }^{1}$ Researcher, ${ }^{2}$ Research Scholar \\ ${ }^{1 \& 2}$ Department of Management Studies, University of Kashmir, Srinagar, Jammu \& Kashmir, India \\ *Corresponding author \\ E-Mail: asimamushtaqbhat@gmail.com
}

\begin{abstract}
The paper seeks to examine the difference in leadership styles between male and female managers. Multifactor Leadership Questionnaire was used as a means of evaluation of the leadership styles. The leadership styles chosen for the study include transformational leadership style, transactional leadership style and autocratic leadership. Three banks viz J\&K Bank, SBI and HDFC of Kashmir division of the state of Jammu and Kashmir were selected for the study. The study found that male and female managers varied significantly in exhibiting transformational leadership style. In case of transactional and autocratic leadership styles, no significant difference was found between male and female managers.
\end{abstract}

Keywords: Transactional Leadership, Employment Sector, Gender Difference

\section{INTRODUCTION}

The study of gender diversity and its related challenges and opportunities is gaining importance as more and more women are entering the organisations all over the world. This is due to the changing trend of societies in terms of increased female schooling as well as in response to various policy interventions to promote women liberation and empowerment. Although the proportion of women in the workplace has increased remarkably within the past few decades, women remain vastly underrepresented at the highest organizational levels. The literature shows that women still are under-represented in the management structures of companies all over the world (Adler and Izraeli, 1988; Davidson and Cooper, 1992,). According to Grant Thornton International Business Report (2017), the percentage of women in senior management teams throughout the world has increased by just one percent in the last year i.e., from $24 \%$ in 2016 to $25 \%$ in 2017. The number of organisations with no female participation at senior level has risen from 33\% in 2016 to $34 \%$ in 2017.

India ranked third lowest in having women in leadership roles for the third consecutive year where $17 \%$ senior level executives are women after Japan and Argentina having 7\% and $15 \%$ respectively. Russia ranked first with $47 \%$, followed by Indonesia (46 percent) and Estonia (40 percent). The report further added that $41 \%$ of the Indian businesses surveyed have no women in leadership roles which are 7 points higher than last year. The survey also noted that only $7 \%$ of the senior management (CEO/
Managing Director) roles are held by women in India. (Grant Thornton, 2017).

The above statistics clearly depict that while the barriers in the career advancement of women is a universal phenomenon, but the situation is even worse in the developing countries where the prejudice of accepting women in employment and their upward movement in their careers is more prominent. Women still come across subtle barriers, referred to as the glass ceiling, in their growing career development especially when it comes to attaining the highest positions of management whereas men with equivalent abilities get up the ladder with a comparative ease (Gatrell \& Swan, 2008). Leadership has been a male dominated phenomenon traditionally. Although the female workforce in the organisations increased but leadership studies focusing on women have been sparse until more modern times. This is because women were not considered competent and capable to lead the organisation due to the stereotypes associated with them that got in their way and hindered their progression to the top positions. Furthermore, Eagly and Steffen (1984), in their Social Role Theory claim that gender role stereotypes are not due to the biological differences alone but they are determined in part by the society.

The society associates some stereotypes with the genders which limits their functioning to certain areas. So, females in the earlier phases of their formal employment were pushed to just few career options as teachers, nurses, secretaries, and administrative assistants. They were supposed to be inferior and subordinate to men. Leadership was associated with the masculine traits and thus identified with men than with women. This hampered the growth of women to the top positions in the organisations. Even some women who were able to get into the higher positions were hazy about their role. This is explained by Eagly's Role Congruity Theory (1987), which suggests that female leaders' choices are constrained by threats from two directions: Conforming to their gender role can produce a failure to meet the requirements of their leader role, and conforming to their leader role can produce a failure to meet the requirements of their gender role.

Counteracting the effects of the gender barriers may be achieved by increasing the numerical representations of women in organizations at higher levels. More and more 
women in leading positions have proved not only that they can meet the requirements of their job, completing the assumed tasks, but that they make a change at the level of perceptions in what leadership practices are concerned.

Traditionally women were supposed to use their talents for the good of their households. They were not considered fit to work outside their homes. Various social hindrances got in their way to go out for a formal employment. But World Wars I and II and the consequent absence of men at workplaces created more job opportunities for women. Women were drawn out of their homes to make use of their skills for the good of the organisations. This paved a way for women to enter the formal employment sector. Subsequently, women's participation increased significantly in the organisations. As women advanced from being domestic engineers to working outside their homes, they were pushed to just few career options as teachers, nurses, secretaries, and administrative assistants. Women who were able to secure positions in the business world, however, normally were limited to staff positions of support rather than line positions of power, or leadership positions. So, early 20th century saw women in industrial and clerical jobs. The road to leadership for working women in business has been long-standing with many obstacles (Elmuti et al., 2003; Knutson \& Schmidgall, 1999; Maxwell, 1997). As females are stereotyped as more emotional, friendly and sympathetic, researchers approached this idea to discern whether these stereotypes influence the behavior of genders at workplace as well. Researchers perceived that these stereotypes might influence their leadership style as well. They believed that the leadership style adopted by females ought to be different than their male counterparts. Subsequently, there emerged an interest amongst the researchers to study if and how the gender influences the leadership styles.

Women are as capable as men to take management level responsibilities and that in many respects women managers are even similar to their male colleagues (Kanter, 1977; Herbert and Yost, 1979; Davidson and Cooper, 1992; White et al., 1992; Powell, 1993). But inspite of growing female workforce in the organisations, women managers are underrepresented in the management structures of companies all over the world (Adler and Izraeli, 1988; Davidson and Cooper, 1992, 1993). Despite the various policy interventions at national as well as international level, women still face various forms of segregation in terms of equal opportunities for education, employment, success and advancement in their careers. Men still earn more than women for comparable work and progress more easily up the career ladder than women do. In a large number of organizations women still encounter subtle barriers in their growing career development especially when it comes to attaining the highest positions of management whereas men with equivalent abilities get up the ladder with a comparative ease (Gatrell \& Swan, 2008). This phenomenon of invisible barrier in the career advancement of female managers is commonly termed as 'glass ceiling'.

\section{GENDER DIFFERENCE IN LEADERSHIP STYLE}

According to Adler and Izraeli (1988), there are two contrasting views regarding women in management-the equity view and the complementary-contribution view. The equity view assumes similarity between male and female contributions and propounds to provide equal rights and norms for both men and women. The complementarycontribution view, on the other hand, assumes differences between male and female contributions and propounds to recognize the value of these differences. According to this view the recognized differences have implications for differences in communication styles, influence tactics and leadership styles. So, there are two different schools of thought regarding the gender differences in leadership style. Most of the researchers are in support of complementarycontribution view and few others support equity view. The current study has thus grouped the two views of the researchers under the captions of equity view and the complementary-contribution view. Equity view includes the study of researchers who illustrate that genders do not differ in their preference of leadership style. On the other hand, the studies of researchers who think otherwise are included in the complementary-contribution view.

Equity view includes the studies of those researchers who argue that there are no assessable differences in leadership styles between genders. These researchers assert that leadership styles are highly situational and are not influenced by the gender of a person. The research in this regard, however, is scarce as given in the next section.

The researchers supporting this view argue that men and women differ psychologically in the way they act, from the style in which they communicate to the way in which they attempt to influence others; these gender differences in communication and influence tactics have implications for differences in leadership styles of men and women. Most of the studies in this regard consider two dimensions of leadership behaviour: structuring and supporting. Males are supposed to adopt structuring behaviour and females are thought to be using supporting behaviour of leadership. Various studies conducted by the researcher's overtime are presented in the subsequent section.

\section{RESEARCH METHODOLOGY}

Explanatory research design was followed for the present study. The target population for the study constituted the managerial personnel of the three major banks of Kashmir division: JK Bank, SBI, and HDFC. The total population for the study constituted 905 managers out of which a representative random sample of 100 managers was selected for the purpose of primary data collection. The sample size of 100 was calculated with the help of online sample calculator with confidence level $95 \%$ and confidence interval (margin of error) of 5. 
The primary data was collected from the respondents from the selected organizations with the help of a structured questionnaire. Leadership styles were measured using Multifactor Leadership Questionnaire (MLQ) (Form 5xshort) developed by Bass and Avolio (1995). The secondary data was collected from various books, journals, and other print and electronic publications.

\section{HYPOTHESES}

1. There is no significant difference between male and female leaders in exhibiting transformational leadership style.

2. There is no significant difference between male and female leaders in exhibiting transactional leadership style.

3. There is no significant difference between male and female leaders in exhibiting Autocratic Leadership style

\section{RESULTS AND DISCUSSION}

As explained above, there are two contrasting views regarding the gender difference in leadership. Some scholars argue that male and female leaders differ in their leadership styles while few others negate this view. In this context, the present study attempted to analyze and compare the perception of leadership styles from male and female leaders' perspective. The following sections specify in detail the difference in the three leadership styles vis-à-vis the gender of leaders.

A. Transformational Leadership Style: In the current section, a comparison was made between the male and female leaders' perception regarding the transformational leadership style. The Descriptives of male and female leaders with respect to the dimensions of transformational leadership style is given in the Table I.

TABLE I DESCRIPTIVES OF LEADERS REGARDING TRANSFORMATIONAL LEADERSHIP FACTORS

\begin{tabular}{|c|l|l|c|c|}
\hline \multirow{2}{*}{ Factor } & $\begin{array}{c}\text { Gender } \\
\mathbf{N}=65 \text { (Male) } \\
\mathbf{N = 3 5} \text { (Female) }\end{array}$ & Mean & Std. Deviation & Std. Error Mean \\
\hline \multirow{2}{*}{ IC } & Male & 3.9231 & .47171 & .05851 \\
\cline { 2 - 5 } & Female & 4.1571 & .33806 & .05714 \\
\hline \multirow{2}{*}{ II } & Male & 4.0436 & .46796 & .05804 \\
\cline { 2 - 5 } & Female & 4.2952 & .53334 & .09015 \\
\hline \multirow{2}{*}{ IS } & Male & 4.1487 & .56221 & .06973 \\
\cline { 2 - 5 } & Female & 4.2095 & .43601 & .07370 \\
\hline \multirow{2}{*}{ IM } & Male & 4.1385 & .45507 & .05644 \\
\cline { 2 - 5 } & Female & 4.3286 & .37265 & .06299 \\
\hline
\end{tabular}

Note: II=Idealised Influence, IC=Individualised Consideration, IS=Intellectual Stimulation, IM=Inspirational Motivation

As evident from the table I, female leaders scored higher than their male counterparts on all the dimensions of transformational leadership style. The mean of individualised consideration, idealised influence, intellectual stimulation, inspirational motivation for female leaders was calculated as 4.1571, 4.2952, 4.2095, and 4.3286 respectively whereas for the same dimensions the mean for male leaders was calculated as 3.9231, 4.0436,
4.1487 and 4.1385. The standard deviations and standard error of means for all the factors maintain that the results are reasonably trustworthy.

Next, in order to determine whether the mean responses from the male and female respondents were significantly different from one another two-tailed t-test was used, the details of which are given in Table II.

TABle Ii Gender Wise Comparison Of LEAders' Perception REgarding Transformational Leadership FaCtors

\begin{tabular}{|c|c|c|c|c|c|}
\hline Factor & Gender & Mean & Mean Difference & $\mathbf{t}$ & Sig. (2-Tailed) \\
\hline \multirow{2}{*}{ IC } & Male & 3.9231 & \multirow{2}{*}{-.23407} & \multirow{2}{*}{-2.596} & \multirow{2}{*}{.011} \\
\hline & Female & 4.1571 & & & \\
\hline \multirow{2}{*}{ II } & Male & 4.0436 & \multirow{2}{*}{-.25165} & \multirow{2}{*}{-2.441} & \multirow{2}{*}{.016} \\
\hline & Female & 4.2952 & & & \\
\hline \multirow{2}{*}{ IS } & Male & 4.1487 & \multirow{2}{*}{-.06081} & \multirow{2}{*}{-.556} & \multirow{2}{*}{.580} \\
\hline & Female & 4.2095 & & & \\
\hline \multirow{2}{*}{ IM } & Male & 4.1385 & \multirow{2}{*}{-.19011} & \multirow{2}{*}{-2.117} & \multirow{2}{*}{.037} \\
\hline & Female & 4.3286 & & & \\
\hline
\end{tabular}

Source: Data compilation by the scholar for the present study

Note: II=Idealised Influence, IC=Individualised Consideration, IS=Intellectual Stimulation, IM=Inspirational Motivation 
Except for the intellectual stimulation, the difference was found to be significant in all the dimensions. The difference was highly significant in case of Individualised Consideration $(\mathrm{p}<0.05$, and $\mathrm{t}$ value $=2.596)$, which means that female leaders were more considerate than their male counterparts. It implies that female leaders show more concern towards their subordinates, listen to them, attend to their needs, and are more empathetic, compared to the male leaders. Idealised Influence also showed a significant difference of $\mathrm{p}<0.05$ and $\mathrm{t}$ value of 2.441 , which signifies that female leaders maintain a high moral standard than male leaders and are more trusted and respected by their subordinates. In case of Inspirational Motivation, the significant difference, $\mathrm{p}=.037$ and $\mathrm{t}$ value of 2.117 specifies that female leaders communicate more effectively than male leaders, and hence encourage and motivate their subordinates more as compared to the male leaders. In case of intellectual stimulation, although the means did differ but the difference was insignificant $(\mathrm{p}>0.05)$, which indicates that male and female leaders equally encourage creativity in their followers. Both equally nurture and develop subordinates who think independently.

Next, the Descriptives of male and female leaders were calculated for the transformational leadership as a whole. Two-tailed $t$-test was again used to check whether the difference in mean scores was significant or not. The details are given in the Table III.

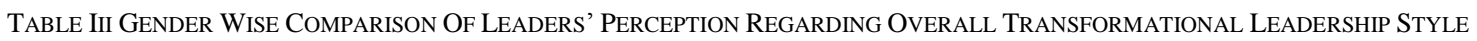

\begin{tabular}{|l|c|c|c|c|c|c|}
\hline Gender & N & Mean & Std. Deviation & Mean Difference & t & Sig. (2-tailed) \\
\cline { 1 - 4 } Male & 65 & 4.0561 & .38509 & -.1993 & -2.596 & .011 \\
\cline { 1 - 3 } Female & 35 & 4.2555 & .32781 & \multicolumn{5}{|c|}{ Source: Data compilation by the scholar for the present study } \\
\hline
\end{tabular}

As clear from the table III, the overall mean score of female leaders for the transformational leadership style as a whole was found to be higher than their male counterparts. Also, the difference was found to be highly significant $(\mathrm{p}<.05)$. The results are contrary to what was assumed in the Hypothesis H1. So, the Hypothesis H1 "There is no significant difference between male and female leaders in exhibiting transformational leadership style" stands rejected which implies that male and female leaders differ in exhibiting transformational leadership style and that female leaders employ transformational leadership style more than male leaders.

B. Transactional Leadership Style: Here a comparison was made between the male and female leaders' view regarding the three dimensions of transactional leadership style. The male and female leaders' perception regarding the three dimensions of transactional leadership style is given in Table IV.

TABLE IV DESCRIPTIVES Of LEADERS REGARDING TRANSACTIONAL LEADERSHIP FACTORS

\begin{tabular}{|l|l|l|c|c|}
\hline \multirow{2}{*}{ Dimension } & $\begin{array}{c}\text { Gender } \\
\mathbf{N = 6 5} \text { (Male) } \\
\mathbf{N = 3 5} \text { (Female) }\end{array}$ & Mean & Std. Deviation & Std. Error Mean \\
\hline \multirow{2}{*}{ CR } & Male & 4.1128 & .56604 & .07021 \\
\cline { 2 - 5 } & Female & 4.0476 & .65251 & .11029 \\
\hline \multirow{2}{*}{ MBEA } & Male & 3.9885 & .39880 & .04947 \\
\cline { 2 - 5 } & Female & 4.0643 & .43447 & .07344 \\
\hline \multirow{2}{*}{ MBEP } & Male & 2.6718 & .64143 & .07956 \\
\cline { 2 - 5 } & Female & 2.9429 & .77748 & .13142 \\
\hline
\end{tabular}

Source: Data compilation by the scholar for the present study

Note: $\mathrm{CR}=$ Contingent Reward, MBEA=Management by Exception Active, MBEP= Management by Exception Passive

As can be seen from the Table IV, the mean scores for management by exception active and management by exception passive were found to be more in case of female leaders whileas in case of contingent reward, the mean was greater in case of male leaders. The means of contingent reward, management by exception active and management by exception passive in case of females were calculated as $4.0476,4.0643$ and 2.9429 respectively whileas for males the means were calculated as $4.1128,3.9885$ and 2.6718 respectively for the same dimensions respectively. The standard deviations and standard error of means for all the factors maintain that the results are practically reliable.
In order to ascertain whether the difference in these means was significant or not, two-tailed $t$-test was performed, the details of which are given below in Table $\mathrm{V}$.

Although the mean scores of the male and female leaders were found to be different but the difference was merely an outcome of chance factor As evident from the Table, the difference was found to be insignificant in all the three dimensions $(\mathrm{p}>0.05)$. The $t$-values for contingent reward, management by exception active and management by exception passive were found to be $.521,-.879$ and -1.869 respectively. 
TABle V Gender Wise Comparison Of Leaders’ Perception Regarding Transactional Leadership Factors

\begin{tabular}{|c|c|c|c|c|c|}
\hline Dimension & Gender & Mean & Mean difference & $\mathbf{t}$ & Sig. (2-tailed) \\
\hline \multirow{2}{*}{ CR } & Male & 4.1128 & \multirow{2}{*}{.06520 . } & \multirow{2}{*}{.521} & \multirow{2}{*}{.604} \\
\hline & Female & 4.0476 & & & \\
\hline \multirow{2}{*}{ MBEA } & Male & 3.9885 & \multirow{2}{*}{-.07582} & \multirow{2}{*}{-.879} & \multirow{2}{*}{.382} \\
\hline & Female & 4.0643 & & & \\
\hline \multirow{2}{*}{ MBEP } & Male & 2.6718 & \multirow{2}{*}{-.27106} & \multirow{2}{*}{-1.869} & \multirow{2}{*}{.065} \\
\hline & Female & 2.9429 & & & \\
\hline
\end{tabular}

Note: $\mathrm{CR}=$ Contingent Reward, MBEA=Management by Exception Active, MBEP= Management by Exception Passive

The above statistics signify that although there was a difference in the means of the aforementioned dimensions between male and female leaders but the difference was not considerable enough to articulate that male and female leaders differ in adopting transactional leadership style. It can be said that male and female leaders exhibited transactional leadership style equally.

Both clarified to the subordinates the work that must be accomplished and provided rewards in exchange for good performance. Likewise both actively monitored the work of followers and made sure that the standards are met. In case of management by exception passive the mean scores of both male and female leaders were below 3 which signify that this very dimension was least adopted by both male and female leaders. Both prefer to intervene before the problem arises and not when the problem arises. Subordinates are provided timely feedback and corrected if necessary and not left on their own by both the leaders equally.

Next, the Descriptive of both male and female leaders were calculated for the transactional leadership as a whole and again two tailed t-test was used to check the significance of the difference as given in the Table VI below:

TABle Vi Gender Wise Comparison Of Leaders' Perception Regarding OVERALl Transactional Leadership Style

\begin{tabular}{|l|c|c|c|c|c|c|}
\hline Gender & $\mathbf{N}$ & Mean & Std. Deviation & Mean Difference & t & Sig. (2-tailed) \\
\hline Male & 65 & 3.6308 & .31619 & -.0921 & -1.245 & .216 \\
\hline Female & 35 & 3.7229 & .41308 & & \\
\hline
\end{tabular}

The overall mean score for transactional leadership style of female leaders was found to be slightly greater than male leaders, calculated as 3.7229 and 3.6308 respectively.

The $\mathrm{t}$ value was calculated as -1.245; however the difference was found to be insignificant with $\mathrm{p}$ value equal to .216. So there was not enough evidence to reject the Hypothesis H2 "There is no significant difference between male and female leaders in exhibiting transactional leadership style implying that male and female leaders are not similar in exhibiting transactional leadership style.

C. Autocratic Leadership Style: Here a comparison was made between the male female leaders' perception regarding the autocratic leadership style. First the Descriptives of the male and female leaders for autocratic leadership style were calculated as given in Table VII.
TABLE ViI DESCRIPTIVE Of LEADERS REgaRding AUTOCRATIC LEADERSHIP

\begin{tabular}{|l|c|c|c|c|}
\hline Gender & N & Mean & $\begin{array}{c}\text { Std. } \\
\text { Deviation }\end{array}$ & $\begin{array}{c}\text { Std. Error } \\
\text { Mean }\end{array}$ \\
\hline Male & 65 & 2.6103 & .66554 & .08255 \\
\hline Female & 35 & 2.6667 & .75840 & .12819 \\
\hline \multicolumn{5}{|c|}{ Source: Data compilation by the scholar for the present study }
\end{tabular}

As evident from the Table VII the standard deviations and standard error of means for all the factors support that the results are reasonably trustworthy. The mean scores of both male as well as female leaders was found to be below 3 which means autocratic leadership style was least exhibited by both. The mean of female leaders was slightly more than that of the male leaders calculated as 2.6667 and 2.6103 respectively. In order to check whether this difference was significant or an outcome of chance factor, $t$-test was performed, the details of which are given in the Table VIII.

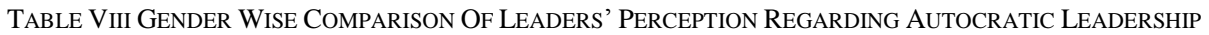

\begin{tabular}{|l|c|c|c|c|c|c|}
\hline Gender & N & Std. Deviation & Mean & Mean Difference & t & Sig. (2-tailed) \\
\hline Male & 65 & .66554 & 2.6103 & -.05641 & -.385 & .701 \\
\cline { 1 - 3 } Female & 35 & .75840 & 2.6667 & \multicolumn{7}{|c|}{ Source: Data compilation by the scholar for the present study } \\
\hline
\end{tabular}


Although there was a slight difference in mean score of male and female leaders but the difference was found to be insignificant $(\mathrm{p}>0.05 ; \mathrm{t}$ value $=-.385)$. So there was not enough evidence to reject the Hypothesis H3 "There is no significant difference between male and female leaders in exhibiting Autocratic Leadership style". It implies that both male and female leaders had similar perception about the autocratic leadership style, and this leadership style was least exhibited by both. Both male and female leaders were not authoritarian towards their subordinates. Both had confidence and trust in employees and took employees into consideration while dealing with significant issues relates to the organisation.

\section{CONCLUSION}

Transformational leadership style has been reported as the most adopted leadership style by both male as well as female managers followed by transactional leadership style. Autocratic leadership style was least adopted by both. Managers varied significantly in exhibiting the transformational leadership style. Overall the female managers were found to be more transformational than their male counterparts; female managers pay more attention towards their subordinate and are more empathetic than their male counterparts. This supports the findings of Petty and Bruning (1980), Korabik and Ayman (1987) and Paris et al., (2009). Female managers have been found to be more democratic, empathetic, friendly, and participative compared to the male managers. Female managers were more considerate and empathetic towards their subordinates. Managers of both the gender did not differ significantly as far as their score on transactional leadership style is concerned. They both exhibited moderate score on transactional leadership style which falls next to transformational leadership style. Though female managers scored more on transactional leadership style than male managers but the difference was found to be insignificant. In the same vein, both male and female managers exhibited similar level of autocratic leadership style. Both showed low level of score on this style. Nevertheless the male managers scored more on autocratic leadership than female managers, but the difference was found to be insignificant.

\section{REFERENCES}

[1] Adler, N. J., \& Izraeli, D. N. (1988). Women in Management Worldwide. Armonk, NY: ME Sharpe.

[2] Bass, B. M., \& Avolio, B. J. (1995). MLQ: Multifactor Leadership Questionnaire for Research: Permission Set. Redwood City, CA: Mind Garden

[3] Davidson M.J. and Cooper C.L. (1992). Shattering the Glass Ceiling -The Woman Manager. London: Paul Chapman Publishing Ltd.

[4] Davidson M.J. and Cooper C.L. (1993). European Women in Business and Management. London: Paul Chapman Publishing Ltd.

[5] Eagly, A. H. (1987). Sex differences in social behavior: A social-role interpretation. Hillsdale, NJ: Erlbaum.

[6] Eagly, A. H., \& Steffen, V. J. (1984). Gender stereotypes stem from the distribution of women and men into social roles. Journal of personality and social psychology, 46(4), 735.

[7] Elmuti, D., Lehman, J., Harmon, B., Lu, X., Pape, A., Zhang, R., \& Zimmerle, T. (2003). Inequality between genders in the executive suite in corporate America: Moral and ethical issues. Equal Opportunities International, 22(8), 1-20.

[8] Gatrell, C. \& Swan, E. (2008). Gender and Diversity in Management: A Concise Introduction. Thousand Oaks, CA: SAGE

[9] Grant Thornton (2017). Women in business: New perspectives on risk and reward, Retrieved on 21 Feb 2018 from https://www.grantthornton.global/insights/articles/women-inbusiness-2017

[10] Herbert S.G. and Yost E.B. (1979). 'Women as Effective Managers: A Strategic Model for Overcoming the Barriers'. Human Resource Management 7, 18-25.

[11] Kanter, R. M. (1977). Some effects of proportions on group life: Skewed sex ratios and responses to token women. American journal of Sociology, 82, 965-990.

[12] Knutson, B. J., \& Schmidgall, R. S. (1999). Dimensions of the glass ceiling in the hospitality industry. Cornell Hotel and Restaurant Administration Quarterly, 40(6), 64-75

[13] Maxwell, G. A. (1997). Hotel general management: Views from above the glass ceiling. International Journal of Contemporary Hospitality Management, 9, 230-235.

[14] Powell G.N. (1993). Women and Men in Management (2nd Ed.). California: Sage Publications.

[15] White B., Cox C. and Cooper C. (1992). Women's Career Development: Blackwell Publishers Oxford 